\title{
Fulfillment of Requirements for the Protection of Rights in the Field of Labor Relations in the Executive Proceedings of Russia

\author{
${ }^{1}$ Damir Kh. Valeev, ${ }^{2}$ Juliya N. Avdonina \\ ${ }^{1,2}$ Kazan Federal University \\ Email:valeev55@gmail.com,kkafedra983@gmail.com
}

Received: 02 ${ }^{\text {nd }}$ November 2018, Accepted: 28 $^{\text {th }}$ November 2018, Published: $3^{\text {st }}$ December 2018

\begin{abstract}
The main objective of executive production consists in ensuring property and other responsibility of the debtor without which the solution of a considerable part of problems of modern Russia is impossible. In article executive production is considered as a final stage of civil and arbitration process in which the main objective of civil and procedural activity is achieved there is a restoration (protection) of the violated subjective rights and interests protected by the law.

For today questions of violation in the field of the labor law become more relevant for this reason this subject for a research was chosen. In article questions posveshcheny to protection of the rights of workers are brought up and problems of system of execution of requirements about protection of the rights in the field of the labor relations in executive production of Russia are solved

During writing of article the law of the Russian Federation "About executive production" was analyzed; the parties of executive production are revealed. The rights and duties of subjects of executive production are analyzed. The characteristic of a legal status of the execution creditor is given. Features of advancing by the execution creditor of expenses on execution in case of absence at the debtor of property or income on which collecting can be turned are revealed. Offers on development of executive production in Russia are formulated.
\end{abstract}

\section{Keywords \\ Protection of the Rights, Executive Production, Execution of the Decision, Labor Relations, Responsibility, Compulsory Execution, Bailiff.}

\section{Introduction}

In the Russian Federation, according to the conventional principles and rules of international law and according to the Constitution of the Russian Federation [1] the rights and freedoms of the person and the citizen admit and guaranteed. [1] Protection of the violated or challenged right or the interest protected by the law as civil, arbitration legal proceedings is one of effective mechanisms of realization of the rights specified in the Constitution of the Russian Federation and freedoms of the person and citizen.

For due performance of acts of vessels there is also executive production as in practice often there is necessary an order of compulsory performance of acts of courts of law, arbitration courts and also acts of other bodies which at implementation of the powers established by the law, were granted the right to assign to citizens, the organizations or budgets of all levels of an obligation for transfer to other citizens, the organizations or in the corresponding budgets of money and other property or commission in their advantage of certain actions or to abstention from commission of these actions.

\section{Methods}

Research methods which were used by us during the studying and the analysis of the questions entering a subject of the real work are the analytical, system, historical method and a method of comparative jurisprudence.

\section{Results and Discussion}

The following concept of measures of compulsory execution is given in p.1 Art. 68 of the Federal law "About Executive Production" [2] it is the actions specified in the executive document or the actions made by the court bailiff for receiving from the debtor of the property, including money which is subject to collecting according to the executive document.

Hardly it is possible to recognize this definition universal as it extends only to cases of property collectings and does not consider specifics of the executive actions which are not connected with the address of collecting on property of the debtor or his salary, other types of income (non-property collectings).

Therefore it is more correct to understand set of the procedural actions of a certain character provided as measures of compulsory execution

According to the p. 3 of Art. 68 of the Law on executive production the following measures of compulsory execution are allocated:

1) the address of collecting on property of the debtor, including on money and securities;

2) the address of collecting on the periodic payments received by the debtor owing to labor, civil or social legal relationship; 
3) the address of collecting on property rights of the debtor, including on the right of receiving payments on executive production in which he acts as the execution creditor, on the right of receiving payments on hiring, rent and also for the exclusive rights to results of intellectual activity and means of individualization, the right of the requirement for contracts on alienation or use of the exclusive right to result of intellectual activity and means [3] individualizations, the right of use of result of intellectual activity or means of individualization belonging to the debtor as the licensee;

4) withdrawal at the debtor of the property awarded to the execution creditor;

5) seizure of the property of the debtor which is at the debtor or at the third parties in pursuance of judicial [4] acts of arrest of property;

6) the appeal to registering body for registration of transition of the right for property, including for securities, from the debtor on the execution creditor in cases and an order which are established by the Law on executive production;

By the legislation also other measures providing execution [5] executive documents can be provided. For example, nullifying the resolution of the court bailiff on seizure of funds of the enterprise, the court illegally recognized that the Law on executive production of 1997 does not provide a possibility of arrest of money [6] which can appear at the enterprise in the future as the list of measures of compulsory execution stated in Art. 45 of the specified Law is not exhaustive, and pronouncement of this resolution is a lawful measure of compulsory execution of the judgment (the FAS determination of the Northwestern Federal District of November 29, 2004 No. A13-6503/04-21). Other example: the arbitration court recognized as reasonable the resolution of the court bailiff which to the debtor it is offered to transfer the cash coming to cash desk into the deposit account of division of service of court bailiffs before full repayment of debt on to a leaf, owing to the fact that Art. 45 of the Law on executive production of 1997 does not contain the exhaustive list of measures of compulsory execution

(item 17 of the Review of practice of hearing of cases, connected with performance of judicial acts of arbitration courts by court bailiffs, the Presidium of the Supreme Arbitration Court of the Russian Federation approved by the information letter of June 21, 2004 No. 77).

The difference of the listed measures of compulsory execution consists in their character. For example, if the requirement of the executive document has the lasting character (collecting alimony, indemnification of life, to health and others), then in most cases as a measure of compulsory execution the address of collecting on the salary, pension, a grant and other types of income of the debtor acts.

However it does not mean that other measures of compulsory execution as usually such cases are specially not provided by the legislation cannot be applied. In certain cases measures compulsory [7] executions can be applied in total. The law also provided a possibility of change of a way and an order of execution (Art. 37 of the Law on executive production).

The stage of executive production is a set of procedural actions which are directed to achievement of a definite purpose.

Each stage of executive production represents group of procedural actions with accurately definite procedural purpose. In most cases this or that stage comes to an end with pronouncement of the resolution of the court bailiff.

As independent stages of executive production it is necessary to allocate:

initiation of executive production;

training of the court bailiff for compulsory execution;

application of measures of the state coercion to the debtor;

appeal of actions of the court bailiff.

The stage of initiation of executive production is characterized by such procedural actions as:

1) presentation of the executive document to the court bailiff;

2) adoption of the executive document by the court bailiff and pronouncement of the resolution on initiation of executive production.

In the theory of executive production there is an opinion that this stage is the only basis of compulsory execution.

In jurisprudence the position according to which the court bailiff has the right to note the resolution on initiation of executive production is developed. In item 8 "The review of practice of hearing of cases, connected with performance of judicial acts of arbitration courts by court bailiffs", the Presidium of the Supreme Arbitration Court of the Russian Federation approved by the information letter No. 77 of May 21, 2004 gives the following example: joint-stock company the execution creditor appealed to arbitration court with the statement for recognition illegal resolutions of the court bailiff on cancellation of the resolution on initiation of executive production. In justification of the requirement the applicant pointed that the Law did not provide a possibility of cancellation by the court bailiff of the resolutions. The arbitration court left the statement without satisfaction on the following bases. As appears from case papers that the court bailiff excited executive production about collecting from the debtor in favor of the execution creditor of amount of debt. Having revealed after that that the court order is shown to execution with the admission of an established period, the court bailiff independently issued the decree on cancellation of the resolution on initiation of executive production. The motivated resolution on cancellation or change of the earlier adopted unreasonable resolution does not forbid the court bailiff to adopt the law. 
As training of the court bailiff for compulsory execution problems of law enforcement and timeliness of commission of executive actions are solved.

By analogy with civil process, training of the court bailiff for compulsory execution is a set of three kinds of activity: intellectual (the court bailiff considers the prospects of development of business); procedural (makes preparatory actions); office work (sends the copy of the resolution on initiation of executive production to the execution creditor, the debtor and also to the court or other body which issued the executive document).

\section{Summary}

During the research we drew the following conclusions:

1. The key moment in the relations of the court bailiff with the persons participating in executive production is protection of the rights and the protected interests and also assistance of the last in implementation of compulsory performance of judicial acts and acts of other bodies which have the right to it.

2. Persons, participating in executive production all those participants of executive production [9] who have a certain legal interest (financially - and (or) procedural and legal) are and act in executive production or on its own behalf, or on behalf of other persons in protection of the interests, interests of other persons, the state and public interests.

\section{Conclusion}

Executive production is one of important stages of civil process and represents the order of compulsory implementation of acts of jurisdictional bodies for disputes of property and non-property character established by the law. Performed by disputes of non-property character as in scientific literature they are less studied are the most difficult, and the legislation on executive production regulates an order of execution of executive documents of non-property character only on restoration at work, to eviction and installation, without considering other groups of the non-property relations that it in turn reduces efficiency of their execution. In this regard, authors chose this subject for a research.

\section{Acknowledgements}

The work is performed according to the Russian Government Program of Competitive Growth of Kazan Federal University.

\section{References}

[1] The constitution of the Russian Federation" (accepted by national vote 12.12.1993) / the Legal-reference system "Consultant Plus" [An electronic resource]. Access mode: $<$ http://www.consultant.ru $>$.

[2] Federal law on "Executive production" of October 2, 2007 N 229-FZ, "Consultant Plus" [An electronic resource]. Access mode: http://www.consultant.ru, free.

[3] Poljakova L.A.dministrative manufacture on acceptance of standard legal certificates in federal enforcement authorities $<$ https:/elibrary.ru/item.asp?id=16985638>//Современное is right $<$ https://elibrary.ru/contents.asp?id=33694131>. 2011. No. $2<$ https://elibrary.ru/contents.asp?id=33694131\&selid=16985638>. Page 28-33.

[4] Valeev Damir Kh., Zagidullin Marat R., Sitdikov Ruslan B., The Rights and Duties of Foreign Person in an Arbitration Procedure in the Russian Federation//HELIX. - 2018. - Vol.8, Is.1. - P.2439-2442. $<$ https://repository.kpfu.ru/?p_id=182648>

[5] Marat Rashidovich Zagidullin SYSTEMATIZATION OF THE SOURCES OF INTERNATIONAL JURISDICTION IN CIVIL CASES OF RUSSI/Marat Rashidovich Zagidullin, Ruslan Borisovich Sitdikov, Talgat Mansurovich Fakhrutdinov, Alina Radikovna Gaifutdinova//QUID 2017. - $\quad$ Special Issue N1. $\quad$ - pp. $1463-1468$. $<$ https://repository.kpfu.ru/?p_id=184150>

[6] Sitdikov Ruslan Borisovich, Zagidullin Marat Rashidovich, Valeev Damir Khamitovich, CLASSIFICATION OF THE MEASURES OF LEGAL RESPONSIBILITY IN THE ENFORCEMENT PROCEEDINGS//QUID-INVESTIGACION CIENCIA Y TECNOLOGIA. - 2017. - Vol., Is.28. - P.1315-1321. <https://repository.kpfu.ru/?p_id=170640>

[7] Marat Rashidovich Zagidullin SYSTEMATIZATION OF THE SOURCES OF INTERNATIONAL JURISDICTION IN CIVIL CASES OF RUSSI/Marat Rashidovich Zagidullin, Ruslan Borisovich Sitdikov, Talgat Mansurovich Fakhrutdinov, Alina Radikovna Gaifutdinova//QUID 2017. - $\quad$ Special Issue N1. - pp. $\quad 1463-1468$. $<$ https://repository.kpfu.ru/?p_id=184150>

[8] Maleshin D.Ya. Court in the course of performance of judicial resolutions: Law PhD Thesis. M, 2002; Maleshin D.Ya. Executive production (function of court). M.: Gorodets-izdat, 2003.

[9] Vikut M.A., Zaytsev I.M. Civil process of Russia: Textbook. M.: Yurist, 1999. Page 224.

[10] - Zagidullin M. R. To a question of responsibility for non-execution of the executive document by bank or other credit institution in executive production/masculine Zagidullin//the Messenger of TISBI. 2002. No. 3. - Page 110-117. $<$ https://repository.kpfu.ru/?p_id=145507> 